ISSN = 1980-993X - doi:10.4136/1980-993X
www.ambi-agua.net
E-mail: ambi-agua@agro.unitau.br
Tel.: (12) 3631-8004

\title{
Occurrence of pesticides from coffee crops in surface water
}

\author{
doi: $10.4136 / a m b i-a g u a .1053$
}

\author{
Alexandra Fátima Saraiva Soares ${ }^{1}$; Mônica Maria Diniz Leão ${ }^{1}$; \\ Vanessa Heloisa Ferreira de Faria ${ }^{2}$; Márcia Cassimira Marcos da Costa ${ }^{2}$; \\ Ana Clara Mourão Moura ${ }^{3}$; Vladimir Diniz Vieira Ramos ${ }^{3}$; \\ Márcio Ribeiro Vianna Neto ${ }^{1}$; Elizângela Pinheiro da Costa ${ }^{1}$ \\ ${ }^{1}$ Universidade Federal de Minas Gerais (UFMG) - Belo Horizonte, MG, Brasil \\ Department of Sanitary and Environmental Engineer \\ ${ }^{2}$ Fundação Ezequiel Dias (FUNED) - Belo Horizonte, MG, Brasil \\ Pesticide Residue Laboratory \\ ${ }^{3}$ Universidade Federal de Minas Gerais (UFMG) - Belo Horizonte, MG, Brasil \\ School of Architecture - Department of Urban Planning \\ *Corresponding author: e-mail: asaraiva.soares@gmail.com, \\ monica@desa.ufmg.br, vanessa.faria@funed.mg.gov.br, \\ marcia.marcos@funed.mg.gov.br, anaclaramoura@yahoo.com, \\ vladimir.diniz@gmail.com, marciorvneto@gmail.com, \\ elizangelapc@gmail.com
}

\begin{abstract}
The excessive amount of pesticides applied in agricultural areas may reach surface water, thereby contaminating it. Thus, the main purpose of this study was to investigate the presence of pesticides used in a sub-basin headwater with coffee crops, situated in the Dom Corrêa district, Manhuaçu, Minas Gerais. The region of study is a great producer of coffee. Crops occupy steep areas and are situated close to surface water bodies. In this study, four sample collection points were selected in streams as well as a point in the distribution network and two points in the water treatment station (raw and treated water) a total of seven points. The samples were collected in rainy and dry seasons. Organochlorines, organophosphates, pyrethroids, carbamates and triazoles pesticides were identified by liquid and gas chromatography analysis with tandem mass spectrometry. The occurrence of pesticides was more evident in the rainy season. A total of 24 distinct pesticides were detected. At least one pesticide was identified in $67 \%$ of the samples collected during the rainy season and in $21 \%$ of the samples collected during drought. Many pesticides detected in water are not regulated in Brazilian legislation regarding potability.
\end{abstract}

Keywords: organic micro-pollutant, surface water contamination, environmental science.

\section{Ocorrência de agrotóxicos de culturas de café em águas superficiais}

\section{RESUMO}

O excedente dos agrotóxicos aplicados nas áreas agrícolas pode atingir as águas superficiais, contaminando-as. Assim, o principal objetivo deste estudo foi investigar a presença dos agrotóxicos em águas superficiais e utilizadas para abastecimento público em uma sub-bacia de cabeceira, com cultivo de café, situada no distrito de Dom Corrêa em Manhuaçu, Minas Gerais. A região de estudo é grande produtora de café, as lavouras ocupam áreas íngremes e situam-se próximas aos cursos d'água. Para isso, foram selecionados quatro pontos de coletas de amostras de água nos córregos, um ponto na rede de distribuição e dois pontos na estação de tratamento (água bruta e tratada), totalizando sete pontos. As amostras 
foram coletadas em período chuvoso e seco. Agrotóxicos organoclorados, organofosforados, piretróides, carbamatos e triazóis foram constatados por meio de análise por cromatografia líquida e gasosa com espectrometria de massas em tandem. A ocorrência de agrotóxicos foi mais evidente no período chuvoso. Vinte e quatro agrotóxicos distintos foram detectados. Pelo menos um agrotóxico foi detectado em $67 \%$ das amostras coletadas, durante a estação chuvosa, e em $21 \%$ das amostras coletadas durante a estação seca. Muitos agrotóxicos detectados não estão relacionados na legislação brasileira de potabilidade.

Palavras-chave: micropoluente orgânico, contaminação de água superficial, ciência ambiental.

\section{INTRODUCTION}

The use of pesticides in coffee crops may contaminate surface water directly from aerial spraying drift, from the erosion of contaminated soil, superficial drainage from rainwater runoff, and also, from the disposal and washing of pesticide tanks and containers. Contaminated surface water can harm aquatic fauna and flora, as well as human health, if used in the public water supply. These products are generally toxic to aquatic organisms, difficult to degrade in the environment and are not removed by conventional treatment methods for drinking water (Soares, 2011; Ormad et al., 2008; Stackelberg et al., 2007).

When pesticides reach the aquatic environment, they are exposed to different physical, chemical and microbiological processes. Holvoet et al. (2007) highlight sorption/desorption and biodegradation as the processes that present greater impact on the final destination of these compounds in the aquatic environment. It is also important to stress the importance of considering the half-life (persistence) of the substances in evaluating their behavior in the environment. Soil characteristics also affect, directly and indirectly, the environmental destination of these substances.

In 2001, the European Union selected 33 organic compounds, including 16 pesticides, as priorities in the control of water pollution (European Union, 2001). Since then, several studies have been developed to detect pesticides in water and to search for alternatives to find increasingly restrictive standards for water quality involving these compounds (Grützmacher et al., 2008; Bortoluzzi et al., 2006; Corbi et. al, 2006; Filizola et al., 2005; Cerejeira et al., 2003).

Data recently published by Brazilian Institute of Geography and Statisctics (IBGE, 2012) indicated that several Brazilian cities have declared that the sources of public water supply, mainly surface waters, are polluted by pesticides.

Thus, the study of water quality in agricultural areas is appropriate in the state of Minas Gerais, Brazil, which produces approximately $48 \%$ of the coffee in Brazil. The Zona da Mata, Jequitinhonha, Mucuri, Rio Doce, Central, and Northern regions provide 32\% of all coffee produced in the state (Soares, 2011). Moreover, data presented by the Health Secretary of Minas Gerais, showed that in 2006, excluding undefined causes, cancer was the second leading cause of death in Manhuaçu, as well in Minas Gerais (Antoniazzi et al., 2009).

Soares et al. (2012a) studied the risk of contamination of water sources by pesticides used on coffee crops, taking into account the amounts of pesticides sold in Manhuaçu, MG between 2007 and 2010, the physic-chemical properties of the active ingredients, their behavior in the environment (fugacity), the potential to cause cancer and the estimate of risk of contamination of surface waters using the algorithm of Goss (1992). The authors concluded that some pesticides used and marketed in this area may contaminate the water and cause cancer, according to IUPAC (2010).

The main purpose of this study was to investigate the presence of pesticides used on coffee crops in a sub-basin headwater situated in Dom Corrêa district, Manhuaçu, MG. This 
study is based on the hypothesis that intensive use of pesticides and conditions of mountains relief, rain intensity and proximity of crops to streams lead to contamination of surface water by pesticide residues.

\section{MATERIALS AND METHODS}

\subsection{Study Region}

Manhuaçu is located in the Rio Doce water basin in Minas Gerais and stands out among other cities in the state for its significant coffee production, more than 20,000 tons in 2009 (IBGE, 2010). There are about 20 thousand coffee-producing properties in Manhuaçu region. This number represents $71 \%$ of the coffee-producing properties in the Zona da Mata, the second-largest coffee-producing region in the state (Soares, 2011).

The local topography is mountainous, with altitudes ranging from 561 to 1,760 meters. The average annual rainfall is $1,860 \mathrm{~mm}$. Rainfall in the region, according to a field survey, occurs predominantly during the months of November through March (Soares, 2011). The rainy period is the same as that of the application of pesticides.

The water source evaluated in this study was selected using multi-criteria analysis, as shown by Soares et al. (2012b). The sub-basin of the study - located in the Dom Corrêa district - is in the upper-left corner of the polygon: $\mathrm{X} 1=-42.17 ; \mathrm{Y} 1=-20.03$; and the lower right corner: $\mathrm{X} 2=-42.10$; $\mathrm{Y} 2=-20.08$ (Coordinates Lat. Long., WGS84), to the north of the city of Manhuaçu, as shown in Figure 1.

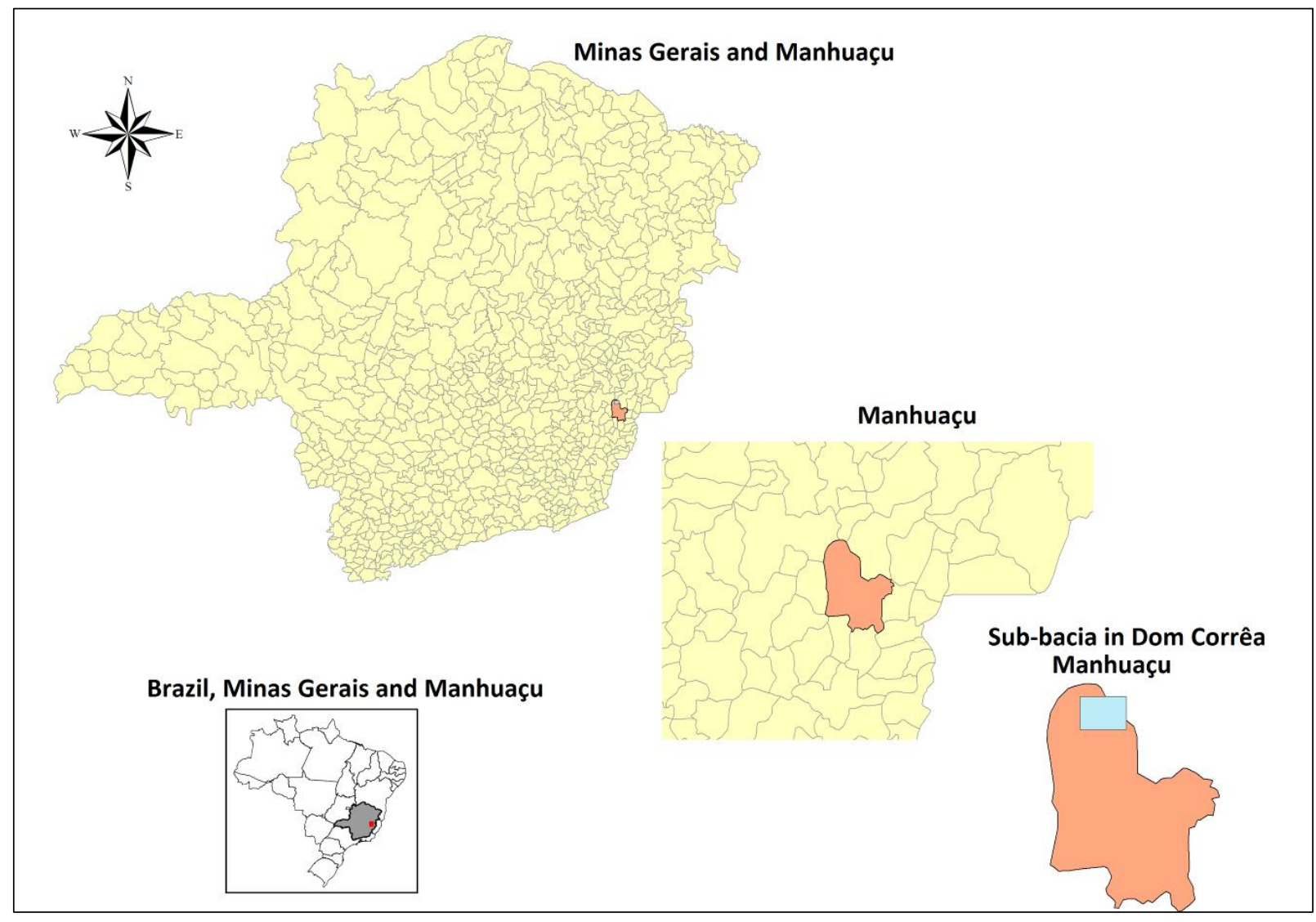

Figure 1. Location Map - Manhuaçu in Minas Gerais and Sub-Basin in Dom Corrêa, Manhuaçu. 
The mean altitude of the sub-basin is $1,143 \mathrm{~m}$, with a minimum altitude of $788 \mathrm{~m}$ and maximum of $1,510 \mathrm{~m}$, a mountainous relief. In the area of study, coffee crops are located near streams. The soil-use map of the sub-basin is shown in Figure 2.

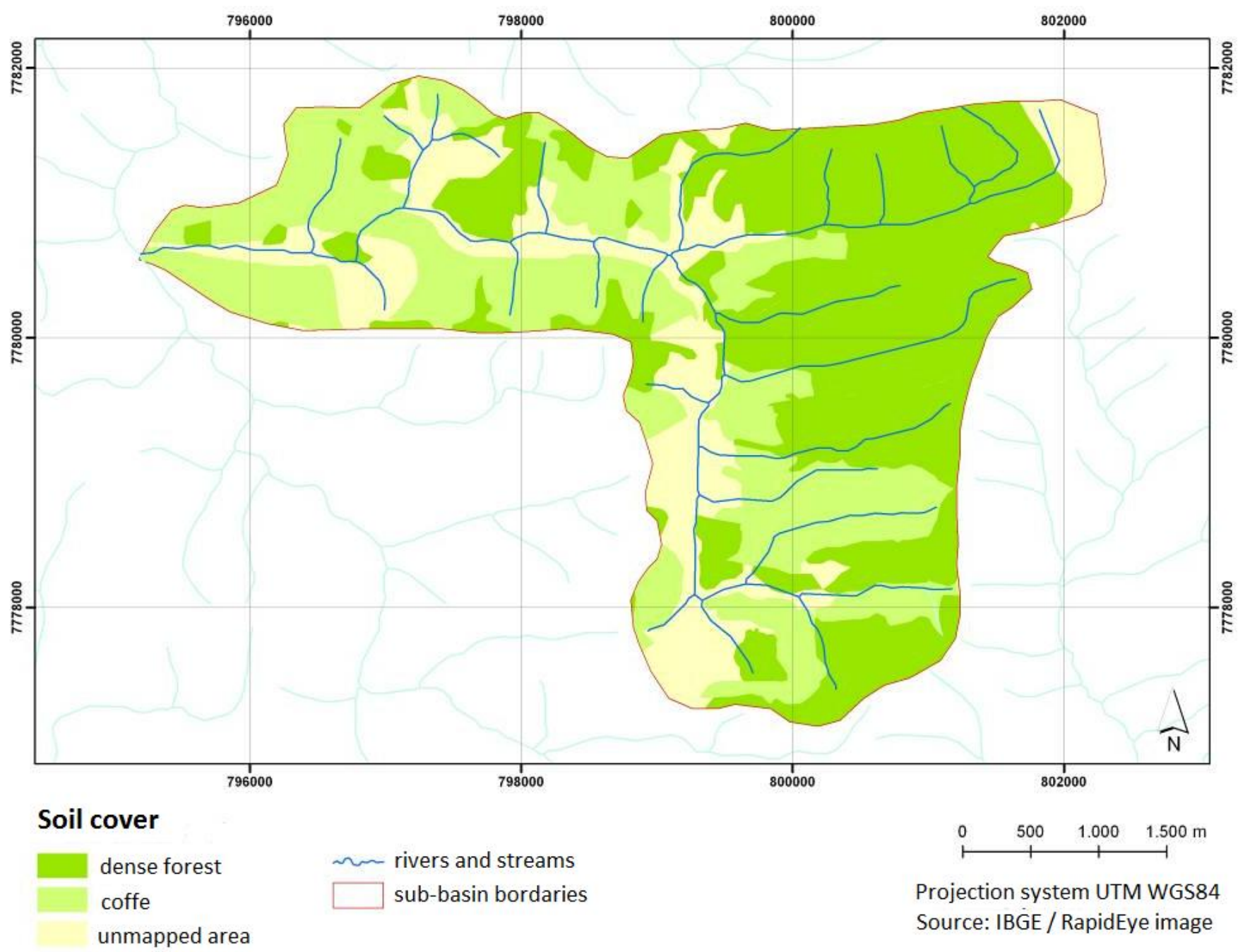

Figure 2. Map of land use in the sub-basin district Dom Corrêa.

The water treatment station (WTS) in the Dom Corrêa District treats water by coagulation-flocculation, decantation and slow filtration in sand. Water sample collection points were chosen to investigate the presence of pesticides during the dry and rainy seasons.

\subsection{Determination of pesticide levels - streams, WTS and distribution network}

To determine the levels of pesticides in the waters, three sample collection campaigns of seven-points each were conducted: two samplings during the rainy season (December, 2010 and March, 2011), and one during the dry season (August, 2011).

Figure 3 shows the locations of the water sample collection points: four points are in the streams, one is at the entrance of the treatment station (WTS: raw water), one after filtration (WTS: treated water), and one in the distribution network downstream of the WTS. 


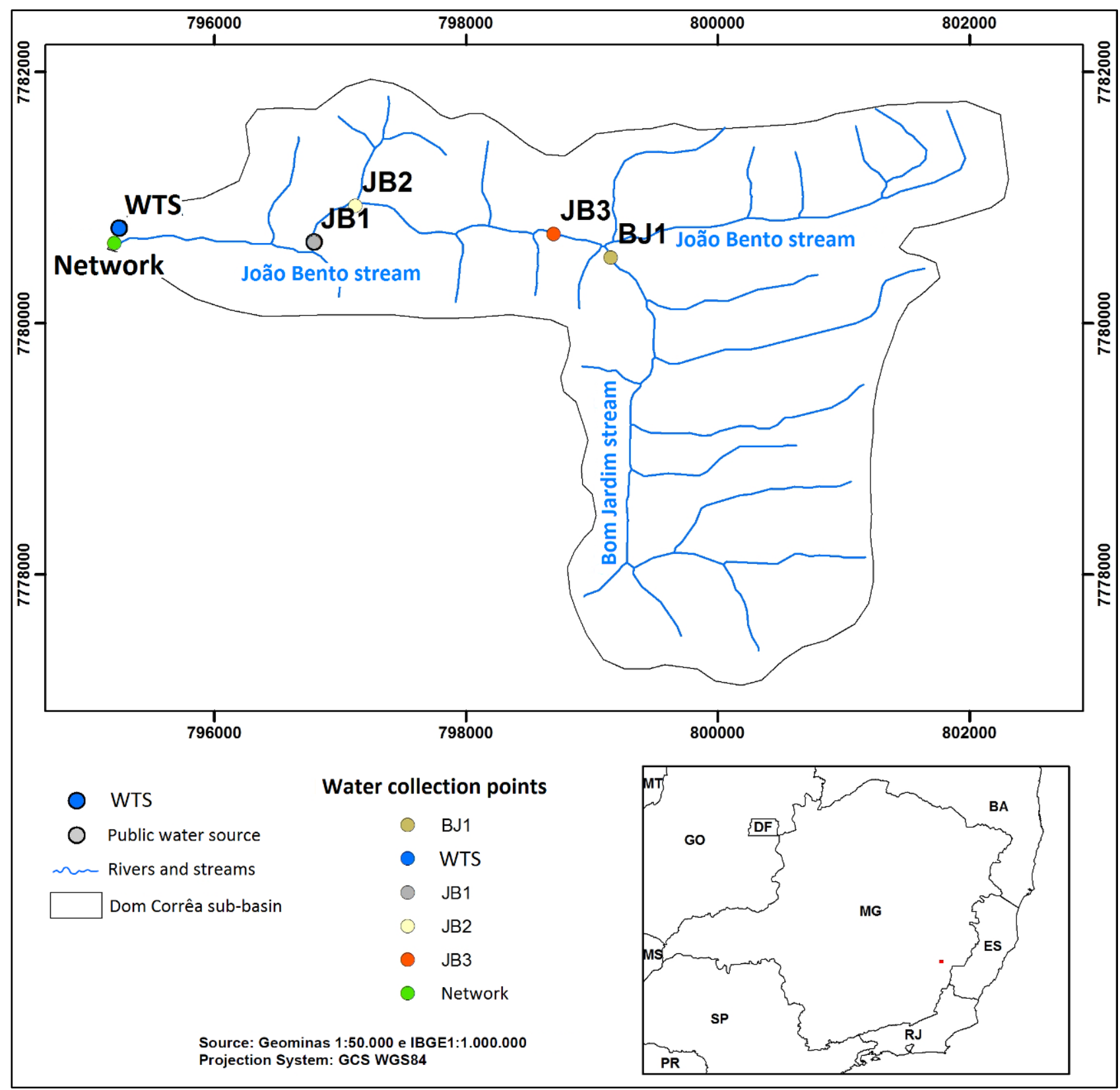

Figure 3. Locations of the water sample collection points.

During each collection campaign, three samples were collected at each point, except in December. Afterward, samples were collected only at points "BJ1" and the raw WTS, while at the point of the distribution network only one sample was collected during the March and August collection campaigns. The 40 samples were analyzed for the presence and amount of pesticides (GC/MS-MS and LC/MS-MS).

Chromatographic analyses, including the extraction procedure, were performed in the Pesticide Residue Laboratory of the Ezequiel Dias Foundation - FUNED - located in Belo Horizonte, Minas Gerais.

This research was considered an exploratory study, since there was no continuous monitoring of water quality of the sub-basin water sources. Analysis of the results of the samples collected in different seasons allows evaluation of the effect of seasonality on the presence of compounds in the water. 


\subsection{Chromatographic analyses}

To perform the chromatographic analyses of the Dom Corrêa district sub-basin stream waters, as well as the WTS and the distribution network, a study of the standards available in the FUNED laboratory was undertaken.

The water samples were collected and kept refrigerated in previously prepared and labeled amber glass. The preparation of the glassware for sample collection included rinsing with Extran Neutro Merck ${ }^{\circledR}$ detergent and drinking water, washing in ultrasound (3 times, 15 min each), drying in an oven $\left(150^{\circ} \mathrm{C}\right.$ for $\left.2 \mathrm{~h}\right)$ and acclimatized with Merck ${ }^{\circledR} \mathrm{n}$-hexane.

The water samples were extracted according to the methodology proposed by FUNED for liquid-liquid extraction, established by Standard Methods for the Examination of Water and Wastewater (APHA, 2005) - $6640 \mathrm{~B}$, adapted, as $500 \mathrm{~mL}$ of each sample were extracted. Following extraction, the samples were injected into the equipment for gas and liquid chromatography with tandem mass spectrometry (GC/MS-MS and LC/MS-MS). All reagents used in the analyses were of chromatographic analytical grade: Merck ${ }^{\circledR}$, J.T.Backer ${ }^{\circledR}$ and Tedia ${ }^{\circledR}$. The standards of pesticides used were Dr. Ehrenstorfer ${ }^{\circledR}$.

The reagents used in the extraction procedure were: acetone f.r.a. (for residue analysis); dichloromethane f.r.a.; n-hexane f.r.a.; common nitrogen gas; granulated sodium sulfate f.r.a., heated to $600{ }^{\circ} \mathrm{C}$ for $4 \mathrm{~h}$; and pesticide standards prepared in acetone.

In the chromatographic analysis, process controllers (surrogate) were added to the samples prior to extraction. $100 \mu \mathrm{L}$ of chlorpyrifos-methyl (3.0 $\mathrm{ng} \mu \mathrm{L}^{-1}$; GC/MS-MS) and $100 \mu \mathrm{L}$ of propoxur (6.0 ng $\mu \mathrm{L}^{-1}$; GC/MS-MS and LC/MS-MS) were used. Blank samples were also analyzed.

Detection limits (DL) and quantification limits (QL) were determined by recoveries, with three considered the minimum $\mathrm{S} / \mathrm{N}$ ratio for a peak to be detected with certainty, with $\mathrm{S}=$ signals obtained and $\mathrm{N}=$ noises, both in absorbance units (uAbs). The quantitative results considered were those with means between 70 to $120 \%$.

\section{RESULTS AND DISCUSSION}

Tables 1 and 2 show the results of the analyses of pesticide residues in the water samples collected in the Dom Corrêa district sub-basin. These tables also show the pesticides detected in samples collected during the dry period (August, 2011). The results of the samples analyzed by GC/MS-MS were semi-quantitative, since results for recoveries of less than $70 \%$ were shown qualitatively. Results were also qualitative for samples analyzed by LC/MS-MS (presence below the quantification limit - QL).

The presence of pesticides in the collected samples of water was more frequent in rainy season and according to the period of the application of pesticides.

The point of collecting water samples "JB2" (Figure 3) was the most critical in terms of occurrence of pesticides. At this site, eight different pesticides were detected by GC/MS-MS, during the rainy season: Cyfluthrin, DDT, Fenvalerate, Heptachlor, L-cyhalothrin, Metolachlor, Methoxychlor and Mirex. The pesticides detected have low water solubility $20^{\circ} \mathrm{C}$ and a high sorption coefficient normalized to the organic carbon $\left(\mathrm{K}_{\mathrm{oc}}\right)$. Moreover, this point is located close the coffee crops, according to Figure 2. This fact suggests that the contamination of surface waters, in this case, is related to the transport associated with the soil (runoff), according to the study developed by Soares et al. (2012a).

Also at sample collection point "JB1", located close to watershed mouth of Dom Corrêa (Figures 2 and 3), five different pesticides were identified by LC / MS-MS: Pirimicarb, Pirimiphos-ethyl and methyl, Propargite and Terbufos. 
SOARES, A. F. S.; LEÃO, M. M. D.; FARIA, V. H. F.; COSTA, M. C. M.; MOURA, A. C. M.; RAMOS, V. D. V.; VIANNA NETO, M. R.; COSTA, E. P. Occurrence of pesticides from coffee crops in surface water. Ambi-Agua, Taubaté, v. 8, n. 1, p. 62-72, 2013. (http://dx.doi.org/10.4136/ambi-agua.1053)

Table 1. Pesticides detected (GC/MS-MS) in water samples collected in the Dom Corrêa district subbasin.

\begin{tabular}{|c|c|c|c|c|c|c|c|c|c|c|c|c|c|c|}
\hline \multirow[b]{2}{*}{ 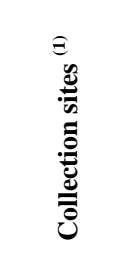 } & \multirow[b]{2}{*}{ } & \multicolumn{13}{|c|}{ Pesticide concentrations $\left(\mu g \mathrm{~L}^{-1}\right)$} \\
\hline & & 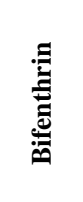 & 窇 & ลิ & 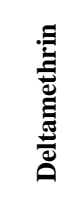 & 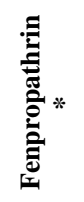 & 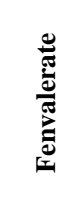 & 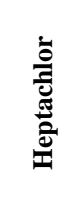 & 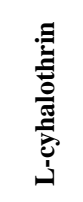 & 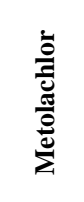 & 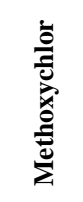 & 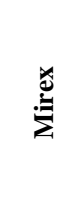 & & 它 \\
\hline BJ1 & $\begin{array}{l}\text { Rain } \\
\text { Dry }\end{array}$ & & & 0.014 & & 0.038 & & & & & & & & \\
\hline JB1 & $\begin{array}{l}\text { Rain } \\
\text { Dry }\end{array}$ & & & & & & & & & & & & & $\mathrm{x}$ \\
\hline JB2 & $\begin{array}{l}\text { Rain } \\
\text { Dry }\end{array}$ & & $\mathrm{x}$ & 0.017 & & & $\mathrm{x}$ & $\mathrm{x}$ & 0.022 & $\mathrm{x}$ & $\mathrm{x}$ & $\mathrm{x}$ & & \\
\hline JB3 & $\begin{array}{l}\text { Rain } \\
\text { Dry }\end{array}$ & & & & & & & & & & & & & \\
\hline Raw WTS & $\begin{array}{l}\text { Rain } \\
\text { Dry }\end{array}$ & $\mathrm{x}$ & & 0.050 & 0.015 & & $\mathrm{x}$ & & & & & & $\mathrm{x}$ & \\
\hline $\begin{array}{l}\text { Treated } \\
\text { WTS }\end{array}$ & $\begin{array}{l}\text { Rain } \\
\text { Dry }\end{array}$ & & $\mathrm{x}$ & $\begin{array}{c}0.019 \\
\mathrm{x}\end{array}$ & & & $\mathrm{x}$ & & & & & & & \\
\hline Network & $\begin{array}{l}\text { Rain } \\
\text { Dry }\end{array}$ & & & 0.016 & & & & & & & & & & \\
\hline \multirow{3}{*}{ Note } & $\begin{array}{c}\operatorname{Rec}^{* *} \text { Qnt } \\
(\%)\end{array}$ & 69 & 66 & 90 & 83 & 73 & 57 & 64 & 76 & 67 & 93 & 65 & 63 & 66 \\
\hline & $\begin{array}{c}\mathrm{DL} \\
\left(\mu \mathrm{g} \mathrm{L}^{-1}\right)\end{array}$ & 0.010 & 0.020 & 0.005 & 0.005 & 0.030 & 0.010 & 0.010 & 0.010 & 0.005 & 0.030 & 0.010 & 0.020 & 0.005 \\
\hline & $\begin{array}{c}\mathrm{QL} \\
\left(\mu \mathrm{g} \mathrm{L}^{-1}\right)\end{array}$ & 0.020 & 0.040 & 0.010 & 0.010 & 0.060 & 0.020 & 0.020 & 0.020 & 0.010 & 0.060 & 0.020 & 0.040 & 0.010 \\
\hline
\end{tabular}

Notes: (*) Collected in December, 2010. (**) Rec: recovery by the method of analysis. (Qnt) quantitative. (DL) detection limit. (QL) quantification limit. (x) Indicates the presence of the substance for recoveries of less than $70 \%$. (1) See Figure 3.

Table 2. Pesticides detected (LC/MS-MS) in water samples collected in Dom Corrêa basin.

\begin{tabular}{|c|c|c|c|c|c|c|c|c|c|c|c|c|c|}
\hline \multirow[b]{2}{*}{ 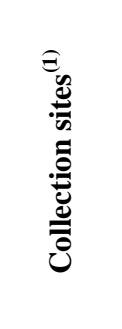 } & \multirow[b]{2}{*}{ 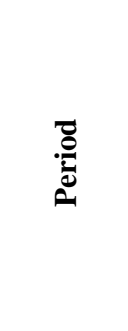 } & \multicolumn{12}{|c|}{ Pesticide detection } \\
\hline & & 胥 & 苞 & 总 & 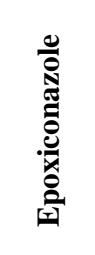 & 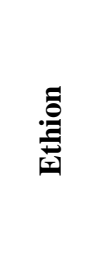 & 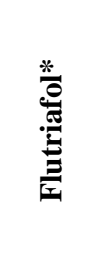 & 栉 & 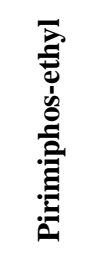 & 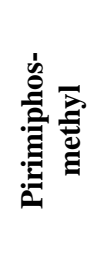 & 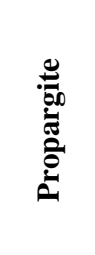 & $\frac{\mathscr{E}}{\stackrel{0}{0}}$ & 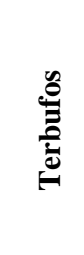 \\
\hline BJ1 & $\begin{array}{l}\text { Rain } \\
\text { Dry }\end{array}$ & & $\mathrm{x}$ & $\mathrm{x}$ & & & $\mathrm{x}$ & & & & & & \\
\hline JB1 & $\begin{array}{l}\text { Rain } \\
\text { Dry }\end{array}$ & & & & & & & $\mathrm{x}$ & $\mathrm{x}$ & $\mathrm{x}$ & $\mathrm{x}$ & & $\mathrm{x}$ \\
\hline JB2 & $\begin{array}{l}\text { Rain } \\
\text { Dry }\end{array}$ & $\mathrm{x}$ & & $\mathrm{x}$ & $\mathrm{x}$ & & & & & & & & \\
\hline JB3 & $\begin{array}{l}\text { Rain } \\
\text { Dry }\end{array}$ & & & $\mathrm{x}$ & & & & & & & & & \\
\hline $\begin{array}{l}\text { Raw } \\
\text { WTS }\end{array}$ & $\begin{array}{l}\text { Rain } \\
\text { Dry }\end{array}$ & & & $\mathrm{x}$ & & $\mathrm{x}$ & & & & & & $\mathrm{x}$ & \\
\hline $\begin{array}{c}\text { Treated } \\
\text { WTS }\end{array}$ & $\begin{array}{l}\text { Rain } \\
\text { Dry }\end{array}$ & & & $\mathrm{x}$ & $\mathrm{x}$ & $\mathrm{x}$ & & & & & & & \\
\hline Network & $\begin{array}{l}\text { Rain } \\
\text { Dry }\end{array}$ & & & $\mathrm{x}$ & & $\mathrm{x}$ & & & & & & & \\
\hline \multirow{2}{*}{ Note } & $\begin{array}{c}\mathrm{DL} \\
\left(\mu \mathrm{g} \mathrm{L}^{-1}\right)\end{array}$ & 0.005 & 0.005 & 0.010 & 0.010 & 0.005 & 0.005 & 0.005 & 0.005 & 0.005 & 0.005 & 0.005 & 0.005 \\
\hline & $\begin{array}{c}\mathrm{QL} \\
\left(\mu \mathrm{g} \mathrm{L}^{-1}\right)\end{array}$ & 0.010 & 0.010 & 0.020 & 0.020 & 0.010 & 0.010 & 0.010 & 0.010 & 0.010 & 0.010 & 0.010 & 0.010 \\
\hline
\end{tabular}

Notes: (*) Collected in December, 2010. (DL) detection limit. (QL) quantification limit. (x) indicates the presence of the substance, recoveries less than the QL. (1) See Figure 3. 


\subsection{Rainy season}

DDT was detected in one of the samples collected after the filtration stage at the Dom Corrêa WTS $\left(0.019 \mu \mathrm{g} \mathrm{L}^{-1}\right)$. This organochlorine was also detected in other Brazilian surface sources at concentrations between $0.97-110 \mu \mathrm{g} \mathrm{L}^{-1}$, according to research by Corbi et al. (2006). However, in the effects of these concentration levels on human health and on the ecosystem are still being studied. Other organochlorine insecticides (heptachlor, methoxychlor and mirex) were also detected by GC/MS-MS during this period. Although their use is illegal in Brazil, these pesticides remain in the environment (mainly in soil and sediment, due to their high persistence) and, because of the rains, can be washed away or transferred from the sediment to the water column, thereby contaminating it. Organochlorine pesticides were also detected in Brazilian surface waters by Corbi et al. (2006); Filizola et al. (2005); Rissato et al. (2004) and Brito et al. (2001).

Pyrethroids (bifenthrin, cyfluthrin, permethrin, fenvalerate, deltamethrin and lambdacyhalotrin) were also detected in this study.

Results of the liquid chromatographic analyses (LC/MS-MS) indicated the presence of ametryn, atrazine, chlorpyrifos-ethyl, ethion, flutriafol, primicarb, pirimiphos-ethyl, pirimiphos-methyl, propargite, temephos and terbufos. The pesticides lambda-cyhalotrin and atrazine detected in this study have also been found in surface waters of the Brazilian states of São Paulo and Rio Grande do Sul by Bortoluzzi et al. (2006); Filizola et al. (2005) and Marques (2005).

\subsection{Dry season}

During the dry period, DDT was detected by GC/MS-MS in one of the samples collected after the filtration stage at the Dom Corrêa WTS $\left(0.019 \mu \mathrm{g} \mathrm{L}^{-1}\right)$. This organochlorine was also detected in other Brazilian surface sources at concentrations between 0.97-110 $\mu \mathrm{g} \mathrm{L}^{-1}$, according to research by Corbi et al. (2006). However, in the effects of these concentration levels on human health and on the ecosystem are still being studied.

Epoxiconazole was also detected by liquid chromatography (LC/MS-MS). It is emphasized that the standard for this active ingredient was researched during dry conditions, which may explain why it was found only during this period.

\subsection{General discussion}

Substances detected in this study were also listed in Annex III of the Rotterdam Convention. These substances are considered extremely dangerous and are prohibited in Brazil. They persist in the environment and are found in water during the rainy seasons, and are possibly transported by particles of contaminated soil.

Many pesticides, detected semi-quantitatively in the waters of the Dom Corrêa district sub-basin, are not regulated by Brazilian legislation for drinking water (Ordinance of the Ministry of Health $\mathrm{n}^{\mathrm{o}}$ 2.914/2011). Among them are bifenthrin, cyfluthrin, deltamethrin, fenpropathrin, fenvarelatale, L-cyhalothrin, mirex, pirimiphos, amethrin, epoxiconazole, ethion, flutriafol, pirimicarb, pirimiphos, propargite and temephos. Two other compounds found in the waters (chlorpyrifos and terbufos) were recently added to the latest revision of legislation involving drinking water. It is important to point out that Brazilian legislation must take into account the most frequently used pesticides and those which have the greatest contamination potential to water. Andreoli and Ferreira (1998) observed this, and also found pesticides related to water quality that was unregulated by Brazilian legislation. At the time of their research, the pesticides detected were not the most used in the area of study. Therefore, the authors proposed monitoring of the five most widely used pesticides in each watershed in order to find alternatives and establish more effective control in the use of these products while taking into account the seasonality of agriculture. 


\section{CONCLUSIONS}

1. The presence of pesticides, mainly from the organochlorine, organophosphate, pyrethroid, triazole and carbamate chemical groups, was found in the waters of the sub-basin of the Dom Corrêa district, Manhuaçu, MG.

2. A total of 24 distinct pesticides were detected. At least one pesticide was identified in $67 \%$ of the samples collected during the rainy season and in $21 \%$ of the samples collected during drought.

3. There is great concern about the consequences of pesticide residues detected in surface water that is near to crops, due to potential and harmful effects to public health. Thus, the headwater areas of hydrographic basins must be preserved and agriculture areas must not be developed near streams, in accordance with the Brazilian Forestry Code and other pertinent legislation.

\section{ACKNOWLEDGMENTS}

The authors are grateful to FAPEMIG e CNPq for their financial support and scholarship, to FUNED for support in conducting chromatographic analyses and to Public Ministry of Minas Gerais.

\section{REFERENCES}

ANDREOLI, C. V.; FERREIRA, A. C. Levantamento quantitativo de agrotóxicos como base para a definição de indicadores de monitoramento de impacto ambiental na água. Revista Sanare, Curitiba, v. 10, n. 10, p. 30-38, 1998.

AMERICAN PUBLIC HEALTH ASSOCIATION. Standard methods for the examination of water and wastewater. 21th ed. Washington, DC, 2005.

ANTONIAZZI, B. N.; D’ALESSANDRO, T. A. L.; TEIXEIRA, R. A. Program evaluation and monitoring of cancer of the state of Minas Gerais. Manhuaçu: Secretariat of Health Surveillance of Manhuaçu. Superintendent of Epidemiology, 2009. Report submitted by the Office GS-183/09.

BORTOLUZZI, E. C.; RHEINHEIMER, D. S.; GONÇALVES, C. S.; PELLEGRINI, J. B. R.; ZANELLA, R.; COPETTI, A. C. C. Contaminação de águas superficiais por agrotóxicos em função do uso do solo numa microbacia hidrográfica de Agudo. Revista Brasileira de Engenharia Agrícola e Ambiental, Campina Grande, v. 10, n. 4, p. 881887, 2006. http://dx.doi.org/10.1590/S1415-43662006000400015

BRITO, N. M.; AMARANTE JR., O. P.; ABAKERLI, R.; SANTOS, T. C. R.; RIBEIRO, M. L. Risco de contaminação de águas por pesticidas aplicados em plantações de eucaliptos e coqueiros: Análise Preliminar. Revista de Ecotoxicologia e Meio Ambiente, Curitiba, v.11, p. 93-114, 2001.

CEREJEIRA, M.J.; VIANA, P.; BATISTA, S.; PEREIRA, T.; SILVA, E.; VALÉRIO, M. J. et al. Pesticides in Portuguese surface and ground waters. Water Research, v. 37, n. 5, 1055-1063, 2003. http://dx.doi.org/10.1016/S0043-1354(01)00462-6 
CORBI, J. J.; STRIXINO, S. T.; SANTOS, A.; DEL GRANDE, M. Diagnóstico ambiental de metais e organoclorados em córregos adjacentes a áreas de cultivo de cana-de-açúcar (Estado de São Paulo, Brasil). Química Nova, São Paulo, v. 29, n. 1, p. 61-65, 2006. http://dx.doi.org/10.1590/S0100-40422006000100013

EUROPEAN UNION. Decision $n^{\circ} 2455 / 2001 / E C$ of the European Parlament and of the Council of 20 November 2001 establishing the list of priority substances in the field of water policy and amending, Directive 2000/60/EC. Official Journal of the European Communities, L331/1, 2001.

FILIZOLA, H. F.; FERRACINI, V. L.; ABAKERLI, R. B., GOMES, M. A. F. Monitoramento de agrotóxicos e qualidade das águas em área de agricultura irrigada. Revista Brasileira de Agrociências, Pelotas, v. 11, n. 2, p. 245-250, 2005.

GOSS, D. W. Screening procedure for soils and pesticides for potential water quality impacts. Weed Technology, v. 6, n. 3, p. 701-708, 1992.

GRÜTZMACHER, D. D.; GRÜTZMACHER, A. D., AGOSTINETTO, D.; LOECK, A. E.; ROMAN, R.; PEIXOTO S. C. et al. Monitoramento de agrotóxicos em dois mananciais hídricos no sul do Brasil. Revista Brasileira de Engenharia Agrícola e Ambiental, Campina Grande, v.12, n.6, p.632-637, 2008. http://dx.doi.org/10.1590/S141543662008000600010

HOLVOET, K.; SEUNTJENS, P.; VANROLLEGHEM, P. A. Monitoring and modeling pesticide fate in surface waters at the catchment scale. Ecological Modelling, v. 209, n. 1, p. 53-64, 2007. http://dx.doi.org/10.1016/j.ecolmodel.2007.07.030

INSTITUTO BRASILEIRO DE GEOGRAFIA E ESTATÍSTICA - IBGE. Levantamento sistemático da produção agrícola - 2010. Available in: 〈http://www.ibge.gov.br〉. Access in: Oct. 2011.

INSTITUTO BRASILEIRO DE GEOGRAFIA E ESTATÍSTICA - IBGE. Atlas de saneamento 2011. Available in: <http://www.ibge.gov.br/home/estatistica/populacao/ atlas_saneamento/default_zip.shtm>. Access in: Nov. 2012.

INTERNATIONAL UNION OF PURE AND APPLIED CHEMISTRY - IUPAC. Pesticide properties database (PPDB): human health and protection. Available in: <http://sitem.herts.ac.uk/aeru/iupac/index.htm>. Access in: Nov. 2010.

MARQUES, M. N. Avaliação do impacto de agrotóxicos em áreas de proteção ambiental, pertencentes à bacia hidrográfica do Rio Ribeira de Iguape, São Paulo: uma contribuição à análise crítica da legislação sobre o padrão de potabilidade. $198 \mathrm{f}$. 2005. Thesis (Doctoral in Nuclear Technology) - Instituto de Pesquisas Energéticas e Nucleares, São Paulo, 2005.

ORMAD, M. P.; MIGUEL, N.; CLAVER, A.; MATESANZ, J. M.; OVELLEIRO, J. L. Pesticides removal in the process of drinking water production. Chemosphere, v. 71, $\mathrm{n}$. 1, p. 97-106, 2008. http://www.sciencedirect.com/science/help/doi.htm

RISSATO, S. R.; LIBÂNIO, M.; GIAFFERIS, G. P.; GERENUTTI, M. Determinação de pesticidas organoclorados em água de manancial, água potável e solo na região de Bauru (SP). Química Nova, São Paulo, v. 27, n. 5, p. 739-743, 2004. http://dx.doi.org/10.1590/S0100-40422004000500012 
SOARES, A. F. S. Uso de agrotóxicos, contaminação de mananciais e análise da legislação pertinente: um estudo na região de Manhuaçu-MG. 294f. 2011. Doctoral thesis (Doctoral in Sanitation, Environment and Water Resources) - Universidade Federal de Minas Gerais, Belo Horizonte, 2011.

SOARES, A. F. S.; LEÃO, M. M. D.; VIANNA NETO, M. R.; OLIVEIRA, S. M. A. C. Risk estimate of water contamination by pesticides used in coffee crops. Revista Brasileira de Engenharia Agrícola e Ambiental, Campina Grande, v.16, n.4, p. 425- 432, 2012a. http://dx.doi.org/10.1590/S1415-43662012000400013

SOARES, A. F. S.; MOURA, A. C. M.; LEÃO, M. M. D.; RAMOS, V. D. V. Critérios para seleção do manancial mais suscetível à contaminação por agrotóxicos. In: SYMPOSIUM LUSO-BRASILEIRO DE ENGENHARIA SANITÁRIA E AMBIENTAL, 15. 18-21 Mar., Belo Horizonte. Anais... Belo Horizonte: ABES, 2012b. 1 CD Rom.

STACKELBERG, P. E.; GIBS, J.; FURLONG, E. T.; MEYER, M. T.; ZAUGG, S. D.; LIPPINCOTT, R. L. Efficiency of conventional drinking-water-treatment processes in removal of pharmaceuticals and other organic compounds. Science of the Total Environment, v. 377, n. 2-3, p. 255-272, 2007. http://dx.doi.org/10.1016/j. scitotenv.2007.01.095 